In 2002 or 2003, Beverley Gass contacted me and asked if I would be willing to run for the NCLA presidency. I was hesitant and pointed out that I had run once before, in the early 1980s, and lost. But Beverley is a hard person to say "No" to, so she convinced me to run. And I was fortunate enough to win.

As I said in my inaugural address at the 2005 NCLA Conference, I accept this position with a great deal of humility and thanks. I appreciate the trust that the members of the Association have placed in me, and I will work extremely hard over the next two years - with their help - to make NCLA the best library association that it can be. I also accept this position with a great deal of excitement and enthusiasm, because I know that the members will help me take NCLA into its second one hundred years and make it "the place to be" for library staff and library supporters.

What do you think the role of libraries is in the current American society?

I sometimes regret that the U.S. Army has already used the tagline, "Be all that you can be," because I think that is at the heart of the role that libraries play in our society. We help people be all that they can be.

To go back to what I said in response to the first question, libraries are all about improving the lives of individuals and communities. We help people get better at whatever they choose to get better at.

In spite of the conservative stereotype than many people have of librarians, it's really a very radical profession. We really empower people. We give them the tools that they need to grow and improve and take charge of their lives.

In "Lord of the Rings," Elrond tells Aragorn to "Become who you were born to be." In many ways, I think that's the role of libraries and librarians, to help people become who they were born to be.

Are professional organizations such as NCLA and ALA still a productive investment of a librarian's time? Why or why not?

I think that the key aspect of being a professional is that professionals constantly educate themselves. They constantly expand what they know and what they are capable of doing. They don't stand still.

As a library educator, I'm always amazed when people say that they weren't taught such and such in library school. The truth is that library schools can't teach you everything that you'll need to know when you work in the profession. Things constantly change in this world. I got my MLS before microcomputers were even invented, for example. But as a professional, it's my job - in fact, it's my duty - to learn about that technology and anything else that helps me do my job better.

I should add here, by the way, that being a professional has less to do with having a certain degree and more to do with having a certain attitude.

One of the most important aspects of a professional organization like NCLA is that we help with this process of ongoing education. NCLA provides workshops, conferences, opportunities to network with other professionals, and other ways to help people in the profession keep learning and keep growing. Wasn't it Bob Dylan who said, "He not busy being born is busy dying"?

My hope is that the members of the Association will help NCLA achieve its goals so that NCLA can, in turn, help the members achieve their professional goals.

If you had the opportunity to address a group of college graduates, what would you say to recruit these students to a graduate degree and career in librarianship?

When Ross Holt was asked this question at the beginning of his presidency, he responded, "I would say two things, primarily: first, that the library profession keeps you on the Information Age's cutting edge; and second, that it gives you the opportunity to serve the community." I really can't improve on that answer. 


\section{Froum the Prosident}

\section{Robert Burgin, President}

Tell the membership a bit about yourself personally, so that they may get a sense of who you are and what makes you the person you are today.

Fans of the Myers-Briggs personality inventory should know that I'm an INTJ and a very strong one on the Intravert, Thinking, and Judging scales. INTJs tend to believe that everything can be improved, that we can constantly do better. That probably explains my approach to life as well as any short description can.

I hope that I'm able to realize the goal on constant improvement during my presidency of the North Carolina Library Association. I'd like to feel that I helped the Association make improvements that will allow it to continue as a strong and vital professional organization. I'd like to think that I helped a good association get even better.

\section{When did you decide that you wanted to be a librarian?}

As a student, I spent much of my life in libraries, but I stumbled into librarianship as a career. I majored in Religion at Duke University, mainly because I liked thinking about the "big" ideas, but when I graduated, I found out that there wasn't much demand for someone with an undergraduate degree in Religion. So I entered the doctoral program in Philosophy at UNCChapel Hill. Again, I liked thinking about the "big" ideas, but again, I soon realized that the job market for philosophers wasn't all that promising.

A friend of mine (Bob Russell, who went on to be the public library director in Brunswick County and Hickory before moving to Oregon) was entering Library School at Chapel Hill, and I had worked for a few months in the Law School Library at Duke, so I thought that this might be a more practical way to spend my life than reading Wittgenstein and Kierkegaard.

\section{Tell us a little about your career in librarianship.}

When I graduated from UNC, I took the first position that I was offered, Assistant Director at the Onslow County Public Library in Jacksonville, North Carolina. It was a wonderful first job, because I worked with and learned a lot from former NCLA President Patsy Hansel and because I could see that the library was so important in the lives of the people we served.

From there, I moved to Goldsboro, where I served as Director of the Wayne County Public Library. After a couple of years there, I was offered the position of Associate Director of the Forsyth County Public Library, where I served under Bill Roberts, whose list of former employees reads like a Who's Who of American public librarianship.

After serving in that capacity for a few years, I was offered a faculty position at North Carolina Central University's School of Library Science by Ben Speller, who had just taken over the Dean's position there. Ben told me that I could teach and work on my Ph.D. at the same time, and it seemed like an unbelievable opportunity.

I've been with NCCU ever since, with the exception of a two-year "sabbatical" when I worked as the Assistant State Librarian for Information Technology.

\section{Tell us a little about your path to the NCLA presidency.}

I've been involved with NCLA as long as I've been in the profession. When I was in Onslow County in the mid-1970s, I served on the Young Adult Committee of the Public Library Section and I've been serving on committees ever since.

In the early 1980s, Leland Park (who had just been elected President of NCLA) asked me if I would serve as the editor of North Carolina Libraries. I accepted and edited the journal until shortly after going to NCCU, when Frances Bradburn succeeded me. 